\title{
The Logic of Open Grazing in Nigeria: Interrogating The Effect on Sustainable Development
}

\author{
Emma E.0. Chukwuemeka1 ${ }^{*}$, Aduma Aloysius ${ }^{2}$, Maximus I. Eneh ${ }^{2}$ \\ ${ }^{1}$ Department of Public Administration, Nnamdi Azikiwe University Awka Nigeria, Nigeria \\ ${ }^{2}$ Department of Public Administration, Enugu State University of Science and Technology, Nigeria
}

Received: June 25, 2018; Accepted: July 6, 2018; Published: July 13, 2018

*Corresponding author: EMMA E.O. CHUKWUEMEKA, Department of Public Administration, Nnamdi Azikiwe University Awka Nigeria;E-mail: ee.chukwuemeka@unzik.edu.ng

\begin{abstract}
This study sets out to examine the implications of open grazing system on sustainable development in nigeria. It was necessitated by the unprecedented burning of houses, killing and maiming of farmers across different blocs of nigeria. The last few years witnessed violent clashes between pastoralists and crop farmers in various parts of the country over grazing resources which has led to the loss of numerous lives and properties, food shortages arising from abandonment of farm lands and destruction of crops, environmental degradation and conflicts of ethno-religious coloration among the various sections that make up the nigerian state. The study adopted ex-post facto research method. And content analysis method was used as analytical tool. An in-depth survey was carried out adopting focus group discussion, face- to- face interview to complement data got from records. The study revealed among others that pastoralists perceive cattle breeding as government business which should take preeminence over other agricultural activities in nigeria. Any slightest attempt to manhandle their cattle leads to violent conflict between herders and farmers. In the light of the findings, the following major recommendations were proffered. They include: building of ranches in lieu of the proposed cattle colony. The question is who will provide land? It is also recommended that effective regulation of grazing and farming activities in nigeria through efficient land use laws/regulations and administration.
\end{abstract}

Keywords: Pastoralism; herders; farmers; transhumance sustainable development

\section{Introduction}

Livestock have played a pivotal role in the development of human civilizations around the world and continues to play the same role in the present day local and global economy. It has done so by increasing the amount of food and nutrition available to people in four ways - by being a rich source of protein food, fertilizer and by pulling plows. It has also been a good source of raw materials for the leather and clothing industry as well as providing employment to those who keep it. According to [15], the growth of animal husbandry, including greater use of manure from livestock as fertilizer was the first of four factors that contributed to the agricultural revolution that ended the cycle of dearth and hunger that afflicted Europe for centuries. If the above views are correct, then it is imperative that society both at local and global levels must find a way of maintaining a steady production of livestock.

In Nigeria like in other parts of the world, livestock keeping is known to all cultures and groups since ages and the need to provide food of crop and animal origin to meet the ever growing demand of its increasing population has often resulted in opening up of lands hitherto uncultivated. The industry constitutes a very important national resource with a great deal of untapped potentials. This derives from the fact that the country enjoys a tropical climate with distinct wet and dry seasons - a feature that makes it conducive for plant and animal food production. However, due to high population and overcrowding, agricultural production (both for animal and crop food) has intensified. Due to this kind of population-driven agricultural intensification, encroachment on farm lands that were hitherto left uncultivated for natural regeneration of the soil nutrients are fast disappearing, so also are grazing lands which have traditionally provided dry season grazing to pastoralists.

Herding of animals or pastoralism, though practiced in other parts of the country, at least at subsistent level, is a major preoccupation of the Fulani in Nigeria. According to [10], the Fulani own over $90 \%$ of the nation's livestock population which accounts for one-third of agricultural GDP and 3.2\% of the nation's GDP and so their contribution to the local food chain and national food security cannot be overstressed. By constituting the major breeders of cattle, the main source of meat, the most available and cheap source of animal proteins consumed by Nigerians, they indisputably represent a significant component of the Nigerian economy. According to [22], the Fulani are undoubtedly the largest pastoral nomadic group in the world, herding goats, carmel, sheep, horse, mule and cattle. With their dominance in the Sahel region, they are the best known and most numerous of all the pastoral groups in Nigeria [10].

A typical Fulani herdsman keeps and sustains his herd through open grazing. This open or pastoralist system involves young men who do labor intensive herding while the women engage in culinary services, cook and sell animal products in the market, [39,17] According to [13], one of the striking aspects 
of pastoralism in Nigeria is the contrast between its actual complexity and the simplified representations usually made of it. An important aspect of the nomadic Fulani pastoral group as a social unit is that permanent habitation is usually not a cultural trait. Camps are shifted frequently in the dry season and less in the wet season $[12,31]$ reckoned that the Fulani, by their culture, tradition and occupation, have remained an itinerant race who never owned lands nor had any permanent abode. In fact, they cared less about land ownership because they are always on the move. They simply lived with their cattle wherever there was abundance of fodder and absence of tse-tse-fly. This type of grazing has often meant travelling long distances from one point to the other and thus intruding into spaces long claimed by settled farmers and has become the source of potential conflicts between them and the sedentary farming population [38].

As an occupation, they rear different species of cattle, such as the Keteku, Muturu, and Kuri, but the Zebu is identified as the most common [11]. Fulani pastoralists pasture or graze their animals in the uncultivated wetlands during the dry season but with increasing population, leading to agricultural intensification and encroachment as well as factors imposed on them by changing climatic conditions especially in their traditional abode in the Sahel region and the advent of dry season irrigation projects, they have been denied access to this dry season grazing resource. These factors have imposed on them a southward migration to where the grass is much greener.

Arising from this migration and other factors, roaming cows, sheep, and goats, scavenging around school playgrounds, golf courses, government residential areas, street shoulders, and railway sidings both at nights and during the day, have become common sights in our cities. They hinder traffic flows, endanger human and vehicular road users, and exacerbate city congestion, and most often, cause fatal road mishaps. In addition to all these, they mess up the ground and bring flies and stench. Our country's news space have lately become awash with skirmishes between what has come to be known as the migrating Fulani herdsmen and the locals over cattle rustling, damage to crops/farm lands and pollution of the environment, including village streams that serve as the only source of water to the people. These conflicts are mostly prevalent in North Central Nigerian States of Taraba, Nakazawa, Plateau, and Benue where, according to [12], conflicts resulting from open grazing of cattle actually accounted for 35\% of all reported crises between 1991 and 2005.

\section{Statement of the Problem}

In most parts of Nigeria, especially in the southern parts, keeping of ruminants, though still part of a man's wealth; is mainly for subsistent living. In such cases, the ruminants are relatively small in number and are either left to roam the family house or are taken out to the field every morning for sedentary grazing and brought back every evening in a manner that prevents them from straying into cultivated farm lands. Where, for inexplicable reasons, the animals stray into and damages peoples' belongings, such damages, either to crops or to other properties, are adequately compensated by the owner.
In the northern part of Nigeria, especially among the Fulani ethnic group, the story is different. Rather than sedentary pastoralism, nomadic or transhumant pastoralism is the culture. Living their life almost entirely on ruminant animal farming, cattle is noted to be the most important object in Fulani society. The quantity of cattle a Fulani man owns is a sign of his wealth. Saidu, a Fulani pastoralist said, "Our herd is our life because to every nomad, life is worthless without his cattle [32]. A typical Fulani man lives his life around his cattle.

Traditionally, these cattle are herded by taking them round in large numbers to feed in open spaces and uncultivated grass lands in a migratory or nomadic style. This traditional system of feeding animals is known as grazing. The nomadic Fulani group basically spends most of their lives in the bush and are the ones largely involved in clashes between herders and the local farmers [28]. A Fulani herdsman sets out to graze his cattle by looking for pastures, doing so, most times with his wife and children, who assists him in tending to the cattle and rendering other sundry services as they move around in search of greener pastures.

Experts have said that owing to increasing desertification, developmental encroachment and diminishing range lands (grazing resource), this type of transhumant pastoralism is generating a lot of problems to society. As can be observed, food supply insecurity, environmental degradation, stunted economic growth and distorted national integration are some of the problems the country is today contending with. These problems stem both from the skirmishes that occur between herders and farmers as pasturing animals intrude on farmlands and watering points for free pasture, as farmers encroach on cattle routes for more cultivable land. As this happens, Saidu, a local Fulani cattle farmer said, 'what do you expect from us when our source of existence is threatened? The encroachment on grazing fields and routes by farmers is a call for war... Wherever we turn, we find the land reserved for our cattle to feast, taken over by farmers... It becomes difficult for our herd to move and graze without veering into crop fields... Once that happens, the farmers confront us and we have no option but to fight back' [32].

As Haman, cited in Imo noted, cattle farmers suffer material damages when the crop farmers inflict physical injuries on their cattle by using cutlasses, spears or guns or by poisoning the cattle. Crop farmers, on the other hand, cry and argue that the fear of gun wielding cattle herders not only prevent them from going to the farm but that cultivated farm lands and crop yields are destroyed by cattle, resulting in sweeping poverty and unemployment in the land.

As precious human and animal lives are lost and crop yields damaged, food security is not only being hampered but precious manpower to support economic growth is reduced. Again as the animals are taken round through the open grazing system, they do not only pollute a few available water sources to the local people but also (through their destructive activities) bring their breeders and the settled farming communities into conflicts that heighten inter ethnic tensions in the country. As all these happen, analysts are of the view that there is ominous danger 
to national integration and overall sustainability especially as these happenings are perceived by people in the south and northcentral regions of the country as signs of failure, imperialism and favoritism by the President, Muhammad Buhari to his tribesmen, the Fulani,over other ethnic nationalities in Nigeria.

The question that is on the lips of all concerned Nigerians now is, what could have been the remote and immediate dangers posed to the future of our country by a grazing system suspected to be the driver of all these problems and how can the dangers be mitigated in order to place Nigeria on the track of sustainable development? Cracking this nut is the central concern of this study.

\section{Objectives of the Study}

The broad objective of this study is to examine the effect of open grazing system on Nigeria's sustainable development. The specific objectives of the study include:

1. To determine the extent open cattle grazing effect food security t in Nigeria

2. To determine the extent of open cattle grazing disrupts economic growth in Nigeria.

3. To examine the effect of open cattle grazing on national integration.

\section{Hypotheses}

1. Open grazing is detrimental to food security in Nigeria.

2. Open grazing disrupts economic growth in Nigeria.

3. Open grazing is disruptive to national integration in Nigeria.

\section{Literature Review}

\section{Conceptual Framework}

\section{Concept of Open Grazing}

To fully capture the meaning of open grazing, it will be most appropriate to begin by understanding first what is meant by grazing and to link it later with the word open. So, what is grazing?

In agriculture, grazing is a method of feeding in which herbivores or ruminants feed on plants such as grasses and other multi cellular organisms such as algae. Linking the above definition together with the word 'open', we then take open grazing to mean the age-old practice of roaming about with animals in open fields, plains and nearby bushes in search of pasture or food for the animals. It is mostly practiced in Nigeria by Fulani herders who move for days on foot with their herds from the north to the more rain-fed southern parts of the country, pasturing their flock as they go.

Many have come to take this type of animal grazing as an indiscriminate way of grazing with several attendant negative consequences, [41]. The system, which can be described as the opposite of sedentary/settled or ranching system has led breeders (mostly the Fulani) to lead a nomadic lifestyle - moving about with their flock and family all year round, and could be said to be necessitated mainly by the need to save cost, find easy market for the animals, escape drought prone areas, escape conflict and desertification prone zones and to escape from human and livestock diseases.

Everywhere or open grazing system could be said to be appropriate when human and animal populations were small and land was huge, just as the system of shifting cultivation was appropriate then. But over the last few decades, populations of both have exploded, fallow periods have been drastically reduced and weather patterns have changed. Since change is a constant thing in life, some experts believe that changing this culture of primitive or everywhere grazing system has become inevitable. They now view the method as backward, outdated and the people who are into it as uncivilized because it has often led to such issues as cattle rustling (snatching of cattle at gun point or through some other violent means), damage to cultivated farmlands and eventual conflict with sedentary farmers, obstruction of highways, littering and damage to the environment (natural and infrastructural) and neither good for the animals nor for the nomads. At the moment, the system constitutes a serious threat to national security [35].

In order to control this indiscriminate grazing method so that farms, natural vegetation and infrastructure could be safe from destruction by grazers and forestall other associated shortcomings of the system, government established grazing reserves in northern Nigeria and in Obudu in Eastern Nigeria in the 1960s. However, the projects did not continue and free or open animal grazing continued with incidences of farm destruction, violent clashes and deaths in the trail. The clashes have become more violent and bloody when, in recent times, pastoralists who normally went about only with staffs began to carry deadly weapons like locally-made and automatic guns such as AK47 with which they freely attacked their host communities, killing many people in the process (Oyeyipo, and James, 2016).

\section{Concept of Sustainable Development}

[21] Defined developmentas a comprehensive economic, social, cultural and political process which aims at the constant improvement of the well-being of the entire population and of the individuals on the basis of their active, free and meaningful participation in development process and in the fair distribution of benefits resulting there-from. Taking her bearing from this position, she defined Sustainable Development as the process of judicious use and conservation of natural resources for the overall improvement in the quality of life for the present and future generations on long term basis. According to her, the concept of sustainable development was formulated as a welding tool as well as a framework for the realization of economic growth in an environmentally viable world, saying that three interdependent and mutually reinforcing pillars of the concept as recognized world-wide in the transition towards a sustainable society are economic sustainability, environmental sustainability and social sustainability.

However, Sustainable Development as a concept first appeared in the World Conservation Strategy put forward by 
the International Union for the Conservation of Nature (IUCN) in 1980 where economic growth was seen as an enemy of the environment.

Prominent meaning to the concept of sustainable development owe its origin to the former Prime Minister of Norway, Gro Harlem Brundtland, who, in the 1980s, used the term to harp that, considering environmental factors; development "meets the needs of the present without compromising the ability of future generations to respond to their needs" $[33,20]$. According to the direct Government website UK "Sustainable development means a better quality of life now and for generations to come. The concept deals with the continuous improvement in the living standard of citizens and the structural transformation or changes in the productive and distributive input and output systems of the economy (Ojobo, 2005; Ollawa, 1977). Adebayo (2010) argues that sustainable development is the efforts of government (federal, state, or local) to improve the environment and the living conditions of the people in such a way as not to negatively affect generations to come. Similarly, Mohammed (2013) sees sustainable development as "the ability to preserve the existing resources of the state for collective use of citizens while conscious efforts are made to conserve the resources for the future generations", while Oyewo and Badejo, cited in Michael (2016) defined sustainable development as the utilization of resources to meet the economic, social and environmental needs of humans, such that the interest of the present and future generation are served.

The foregoing points to the fact that there is no one universally accepted definition of the term. [3] posited that what is however common to all the definitions concerns resource exploitation at a rate that would not prove detrimental to future generations. Explaining further, he said that sustainable development simply meant not using up resources faster than the planet can replenish. Sustainable development is about the continuous harnessing of resources to enhance the quality of life of citizens. This is in addition to putting in place adequate provision to cater for future generations.

Looking at all the definitions, we can say that Sustainable Development is, therefore, likely to manifest in a country where the leadership is innovative in approach and action. According to Okebukola (2014), innovation is very important to the extent that it galvanizes socioeconomic growth and development of societies. He argues that innovation in an irrigation system, for instance, has revolutionized the agricultural sector for enhanced food production in the developed world.

Sustainable development is able only if deliberate efforts are made by those who are entrusted to manage public resources in a competent manner and are willing to do so for the benefit of all in the society. This is where transformational leadership becomes imperative in the management of public resources for sustainable development. Sustainable development in Nigeria will ensure that future generations have the right to a high standard of living, prevent the crises in resources, show the need for national quality and create the awareness of environmental, economic and social needs of all stakeholders [1]. In line with this theory, the social, economic and ecological factors in Nigeria will have to be bearable, viable and equitable for us to be able to achieve sustainable economy in the country.

\section{Traditional Cattle Grazing System in Nigeria}

[10] noted that herding or grazing of animals in Nigeria is dominated almost entirely by the Fulani tribe. According to him, herding is a daunting task, and contrary to widespread belief, it is not the delight of the Fulani, as they herd, not as a matter of choice but as a necessity. He stated that about $75 \%$ of the sampled nomadic pastoralists maintained that animal herding is not only toilsome, but also becoming increasingly strenuous. An optimum Fulani cattle herd size lies between 80 and 100 . With a preponderance of female over male at 4:1 ratio, the Fulani herdsman maintains a balanced functional species composition that is made up of 'beefers, milkers, breeders, carriers, and stock beautifiers'. The slow-maturing Sokoto Red Cow and the lyrehorned White Fulani cattle is the mainstay of the pastoral Fulani holdings. [10] Disclosed that the White Fulani cattle, though less hardy, has higher milk and beef yield compared to the Sokoto Red.

Cattle belonging to individual family members are usually herded together, with male family members assuming automatic rights to all cattle, making it difficult to determine cattle ownership by female family members. Fulani men possessing less than twenty cows are seen as poor, while women having six cows are considered as rich. Women, however, own most of the small ruminants and all of the poultry [10]. Though most Fulani men herd cattle well pass the middle age, herding is dominated by the youths, while decisions about grazing are mainly made by the elderly family members. The Fulani herdsman makes excellent use of sign language, the cane and verbal command to drive the animals, with faster animals occupying the front rows. During migration, a typical herd consisting of several family units move in a column of up to five meters wide and two kilometers long. And by the time it passes any given point, 'everything that stands at that point is destroyed'.

Describing the annual grazing cycle of the Fulani, [10] stated that the herding season begins with southward movement of the herd along rivers and stream valleys from October to December - marking the end of rainy season and beginning of dry season. January to February is the harmattan season that is characterized by longer grazing hours, herd splitting, and more frequent visits to stable water sources. This thus, increases the southward movement of the herds. The months of March and April are usually the toughest for the herdsman and his herd, as it is the hottest period in the grazing calendar. Indeed, he now herds his cattle only in the evenings and nights [10]. May and June signify the end of dry season and vegetation begins to appear. This also marks the beginning of northward movement of the herds and their herders. From this period up till September, which is the peak of rainy season, though characterized by breeding, more milk production and shorter grazing hours, animal herding coincides significantly with arable crop production- a period during which farmers-herdsmen conflicts become prevalent. 


\section{Impact of Open Grazing System on Food Security and Sustainable Development in Nigeria}

Grazing animals has been noted to have a two sided effect on food production and agriculture generally. For instance, through open grazing, animals can disperse seeds by transporting them in their coats (fur, fleece, or hair), feet, or digestive tracts. For some plant species, grazing ungulates may facilitate seed germination by trampling seed into the soil and through their dung, can produce manure needed by plants to grow. It can as well decrease flower and seed production directly by consuming reproductive structures, or indirectly by stressing the plant and reducing energy available to develop seeds. Grazing of animals can also be a competitor in world food supply with humans. However this is only possible in areas where cattle are pastured in areas perfectly suitable for agriculture, or where they are fed substantial cereal supplements [43].

Generally, the Food and Agriculture Organization (FAO) in its 2011 report noted that livestock production and animal grazing in particular can be seen as lending indispensable support to agriculture as it contributes greatly to food security through:

1. Supply ofglobal calories, proteins, and essential micronutrients,

2. Support to agriculture in areas that have difficulty growing crops.

3. Consumption of the feed that are not appropriate for human consumption, and

4. Provision of manure for crop production (FAO, 2011).

However, there are concerns also that livestock production is detrimental to society. Where animals are grazed the way they are done in Nigeria, the first concern according to Abba and Usman (2008), cited in [19] is that of food security. In all the states studied by the researchers, particularly Taraba and Benue States, the majority of those displaced by herders-farmers clashes are women and youths who make up substantial part of the farming communities, just like in Nakazawa, Kaduna (Southern Kaduna) and Plateau States. These displacements, (stemming from the clashes between herders and sedentary farmers over free grazing rights and instability caused by these incessant clashes), will likely lead to food shortages in the immediate communities in particular and in the general economy.

Worldwide, arable crops enjoy remarkable dominance, playing significant roles in the socioeconomic lives of both rural and urban peoples. Arable crops include a wide range of annual crops of primary importance such as maize, rice, sorghum, millet, cassava, cowpea, wheat, soybeans, melon, groundnut yam, and vegetables and so on. In Nigeria, production of these arable crops is essentially the prominent feature of agricultural activities. Indeed, almost all farmers in Nigeria cultivate one or more arable crops for food and income. According to Fayinka (2004), Nigerian agricultural production is dominated by rural-based small scale arable crop producers, who account for about $80 \%$ of total food requirement. Of an estimated 71 million hectares of cultivable land, only half is currently used for farming. The reasons may largely be due to the worrisome open grazing of animals on farm lands as farmers now helplessly continue to abandon their farms.

In a Thisday Newspaper report of January 30, 2017, the Publicity Secretary of Afenifere Renewal Group (ARG), Mr. Kunle Famoriyo, called for the proscription of open/everywhere grazing system because it is undermining food security in the South Western part of Nigeria. He lamented that the south-west local small-holder farmers could no longer work at their full capacity due to the ruinous activities of Fulani herdsmen and their everywhere grazing system. He argued that the fear of gun wielding cattle herders not only prevent their small-holder farmers from going to the farm but that cultivated farm lands and crop yields are destroyed by cattle, resulting in sweeping poverty and unemployment in the land [23].

On the other hand, Haman [25] revealed that cattle farmers suffer material damages when the crop farmers inflict physical injuries on their cattle by using cutlasses, spears or guns or by poisoning the cattle. [32] noted that about thirty four [34] cattle, eleven [11] sheep/goats and other items valued at over N2.64m were lost from a particular conflict involving farmers and pastoralists. When these incidents happen, shortages, which go to worsen the prevailing food scarcity in the land, are incurred.

As has been widely noted, open grazing especially when there is over indulgence, is a primary contributor to desertification because it converts arable or pasture land into unproductive land. The resultant soil is thus no longer suited for growing food since it loses its essential nutrients. The loss of land productivity directly results in the loss of crop food available for consumption. This heightens food supply reduction and if population growth remains unchecked, it causes starvation and economic challenges. The long term effect of this is food shortages which can make people and cattle die of starvation.

Without sufficient pasture for livestock grazing, herds lack the necessary nutrients for survival. The nutrient deficiencies make the animals unable to gain weight appropriate to their productive stage and life which lowers their chances of survival. Human survival levels, well-being, and health are as well affected when there is inadequate food supply for consumption with the end results being acute starvation and death of both people and livestock.

In the final analysis, it is possible to conclude that even as there are gains that agricultural food production can make from open or everywhere grazing practice, the costs of the system to steady food supply seem to far outweigh the benefits. With the preponderance of internecine conflicts between farmers and herders that accompany the country's animal grazing culture, it remains to be seen how open or everywhere grazing system will enhance steady food production in the economy

\section{Impact of Open Grazing on Environment and Sustainable Development in Nigeria}

The world we live in is our environment. It is an assetall human beings share in common, so the responsibility for protecting it is common to all men. The environment is at the center of the 
concern for environmental sustainability, meaning that the next thing to man's life is his environment [33]. Specifically, the environment includes the natural environment such as the vegetation, land, the atmosphere, open fields, forests and water on one hand and the built environment (infrastructure) like roads, bridges, stadia, hospitals and schools on the other.

Arising from the concern to our environment, there has been a growing volume of criticism in recent years against open grazing of livestock from environmentalists. They argue that even though organic components of feces and urine from grazing animals can build soil organic matter reserves, resulting in soils having increased water-holding capacity, increased water-infiltration rates, and improved structural stability and consequently decreased soil loss by wind and water erosion, grazing of animals (especially when not properly managed) can result into the following:

1. Increased desertification through long term over grazing, particularly in semiarid rangelands;

2. Deforestation by lopping branches for use as fodder and felling trees to make way for pastures.

3. Increased greenhouse gas effect, since grazing ruminants produce methane as an end product of rumen digestion; and

4. Water and environmental pollution through animal wastes.

According to [42], surveys conducted in Benin City, Nigeria showed that most animal food producers are operating outside the boundaries of sustainability because of inadequate waste management and excessive waste produced in small geographical areas, well beyond the assimilation capacity of the local environment. With smallholder farmers, waste could be applied to land used to produce food and other crops. But with development and specialization in livestock production that requires large herds, waste may exceed the carrying capacity of local ecosystem and are a potential cause of a number of pollution and health problems related to their organic matter, nutrients, pathogens, stench, dust and air-borne micro-organisms. It is commonly observed in major farms in Nigeria that animal waste discharges run into rivers and erosion courses. These contribute a substantial amount to river pollution.

According to experts, livestock production and their waste have polluted the environmental in the following ways:

\section{Impact of Open Grazing System on Economic Growth and Sustainable Development in Nigeria}

Beyond doubt, Nigeria is enormously endowed with abundant human and material resources which made it by far the most populous country in Africa. As at 2018, the country's population is expected to be around $196.1 \mathrm{~m}$ (United Nations Department of Economic and Social Affairs: Population Division). As a resource, a chunk of this population will be available as factors of production for economic combination with other resources in productive activities. As consumers, the goal of economic development is to maximize the realization of their desires and aspirations. Thus, any analysis must consider population in both its role as producers and consumers as no national, organizational or institutional setting can function well without human resources. Irrespective of the introduction of modern equipment and other technological inventions, human resources plays significant role in the development, operation and management of an organization. In the same vein, no economy can sustain or endure the vagaries of modern realities without the impact of human resource. Human resources therefore remained at the center of all forms of activities in the economy of a nation.

In the light of the above, it is pertinent to note that both the migrant pastoralists and the local crop farmers all constitute human resources of the nation and both contribute individually or collectively to national development. While migrant pastoralists are carrying their cattle to graze on open spaces, the sedentary crop farmers are heavily affected as the herds destroy crops, farmlands and other agricultural products which often lead to conflicts and confrontations. It was observed that between the year 2000 and 2015, no month passed without a report of conflict between pastoralists and sedentary farmers. From Plateau to Nakazawa, Benue, Taraba, Enugu, Anambra, Abia, Imo States, the media is awash with reports of conflicts between the duo and the conflicts often result in the death of many people and sometimes the dislocation of the entire host communities as observed in Benue, Plateau and Taraba States. Daily Sun of May 20, 2015, reported that 38 people were killed in Benue and Taraba, by Fulani herdsmen. This captured the ugly scenario going on in several States in the country today. Since year 2000 till date, hundreds of people (from both sides) have lost their lives in conflicts arising from open grazing of cattle by herdsmen and its attendant fallouts.

In the same vein, other resources worth millions of naira had been lost and thus increasing aggressive poverty in the affected regions. Considering the number of people killed by these conflicts and confrontations, it becomes glaring that the human resource that engaged in economic activity in the country is being depleted and thereby reducing the productive and consuming strength of the nation. More so, the presence of Fulani herdsmen in the affected areas creates a climate of fear as they carry sophisticated arms and ammunitions with which they unleash terror on the people of the regions and other perceived enemies [2].

These conflicts have exacted a heavy humanitarian toll with thousands killed and tens of thousands displaced. Some estimates suggest that about 2,500 people were killed countrywide in 2016 - a toll higher than that caused by the Book Harem insurgency over the same period. In Benue, one of the hardest-hit states, Governor Samuel Ortom reported that more than 1,878 people were killed between 2014 and 2016 and tens of thousands also displaced. From January 2015 to February 2017, at least 62,000 people were displaced in Kaduna, Benue and Plateau states. In the absence of any arrangement like Internally Displaced Persons (IDP) camps, most of these displaced people seek shelter in other poor, rural communities and end up overstretching the already scarce resources in the area.

The fear of conflict alone can drive residents to relatively more secure urban and semi-urban areas where they contribute 
to worsen the decay of our cities. For women and girls, the impact is frequently magnified. The relatives of men killed in the violence often evict widows from their farmland. Moreover, post-conflict economic and social disenfranchisement renders women and girls even more vulnerable to sexual and economic harassment.

In the same vein, Bashir, cited in [41] observed that cattle rustling and banditry which derive from the nature of our grazing system has had major impact on pastoral livelihoods in Katina State. It has, according to respondents to the study, led to $26.7 \%$ of conflict-related deaths. $22.6 \%$ immigration, $17.2 \%$ of internally displaced persons, $17.2 \%$ of intolerance between communities, $12.8 \%$ high number of police patrol and military personnel, $9.1 \%$ incidence of human rights abuses and $6.1 \%$ of sexual assault. It has also increased arrest and detention of the common people without probable cause or warrant to the tune of $5.4 \%$. Participants in the study also cited the main impacts of cattle rustling as poverty due to source of livelihood being taken away. High number of widows and children also get killed as raiders come into the community. The community has also continuously experienced trauma due to the deaths and anxiety created by unexpected turnouts of cattle rustling in the area.

The International Crisis Group (2017) noted that the economic toll has also been huge. According to a study conducted by the group in 2015 , the federal government was losing $\$ 13.7$ billion in revenue annually because of herder-farmer conflicts in Benue, Kaduna, Nakazawa and Plateau states. The study found out that on average, these four States lost 47 per cent of their internally-generated revenues. In March 2017, Benue State Governor, Samuel Ortom asserted that attacks by herders coming from more northerly States, and possibly also from Cameroon and Niger, had cost his State N95 billion (about \$634 million at that time) between 2012 and 2014 .

Communities and households also pay a heavy price. The ethnic Nzor-Tiv Global Association estimated that its Agatu communities in Benue State lost N65 billion in properties ( $\$ 204$ million) during the early 2016 herdsmen attacks. The loss of large cattle herds, crops (due to population displacements and damage to irrigation facilities), as well as increases in transport and labor costs in post-conflict environments all increase poverty and food insecurity in affected communities - and beyond (International Crisis Group)..

\section{Impact of Open Grazing System on National Integration and Sustainable Development in Nigeria}

Conflicts between nomads and sedentary farmers date back to the earliest written recordsand are mythically symbolized in many cultures. Such conflicts have existed since the beginning of agriculture [22]. They only increased or decreased in intensity and frequency depending on economic, environmental and other factors [10].

According to International Crisis Group, historically, relations between herders and sedentary farming communities have been harmonious. They lived in a peaceful, symbiotic relationship with herders' cattle fertilizing the farmers' land in exchange for grazing rights. But tensions have grown over the past decade, with increasingly violent flare-ups spreading throughout central and southern Nigerian States; with incidents occurring in at least 22 of the country's 36 states. According to one report, in 2016 over 2,000 people were killed and tens of thousands displaced in Benue and Kaduna States alone.

The spread of these conflicts into southern states is aggravating the already fragile relations among the country's major regional, ethnic and religious groups. The south's majority Christian communities resent the influx of predominantly Muslim herders, portrayed in some narratives as an islamisation force' (because herders are mostly Fulani), thereby lending an ethnic dimension to the strife. In March 2016, the prelate of the Methodist Church of Nigeria, Dr Samuel Uche, said: "We are aware that there is a game plan to Islamize Nigeria, and they are using the Fulani herdsmen to initiate it". In the south east, Biafra separatist groups describe the attacks as part of a northern plot to overwhelm the peoples of the south and forcefully convert them to Islam. Some southerners accuse President Buhari of deliberately failing to stop herder aggression, pointing to his pastoral Fulani background and his position as life patron of the Miyetti-Allah Cattle Breeders' Association of Nigeria, (MACBAN), to buttress their charges.

Most worrisome is that the conflicts are becoming more frequent and deadly lately. In 2015 for instance, the Global Terrorism Index (GTI), which is published by Sidney, Australiabased Institute for Economics and Peace labeled Fulani herdsmen as the fourth deadliest global terror organization after Book Harem, the Islamic State in Syria and Iraq and al-Shabab in Somalia [41]. On the threat posed to peace by these conflicts, the International Crisis Group (ICG) in their September, 2017 edition opined that violent conflicts between nomadic herders from northern Nigeria and sedentary agrarian communities in the central and southern zones have escalated in recent years and are spreading southward, threatening the country's security and stability. With an estimated death toll of approximately 2,500 people in 2016 , these clashes are becoming as potentially dangerous as the Book Harem insurgency in the north east. Continuing, the publication said, 'The conflicts, particularly herder attacks on farming communities, have spawned dangerous political and religious conspiracy theories. One is that the attacks are part of a longer-term Fulani plot to displace indigenous populations and seize their lands. Among Christian communities, herder attacks are widely seen as a subtle form of jihad. According to the group, these charges are not supported by any solid evidence, but they are aggravating inter-faith distrust and undermining the country's fragile unity. The Sultan of Sokoto, Mohammed Sa'ad Abubakar III, spiritual head of Nigerian Muslims and a prominent Fulani, has repeatedly stressed that Fulani herders who kill should be prosecuted as criminals and even terrorists, but many remain unconvinced in a country with deep inter-faith suspicions. Communities in the middle belt and south have formed self-defense vigilante groups, some of which have threatened organized reprisals. In March 2014, Leonard Karshima Shilgba, an ethnic Tiv academic and opinion 
leader, warned that if the federal government does not stop the attacks, "the Tiv people would also demonstrate that they equally have the right and also the capacity to raise a standing army of thousands from each ward and kindred". Following an April, 2016 attack on Nimbo, in Enugu State in the south east, MASSOB, a separatist Movement for the Actualization of the Sovereign State of Biafra ordered "Fulani herdsmen to leave Biafra land or ... face our their wrath". In May, 2016, Ekiti State Governor, Ayodele Fayose, warned of possible attacks on Fulani herders if their alleged predatory behaviour vis-à-vis locals continued. And the president of the Christian Association of Nigeria (CAN), Rev. Olasupo Ayokunle, warned: "If the government fails to stop the provocation by the Fulani (herdsmen), they should be prepared for war as no ethnic group has a monopoly of violence and none should be a monster to others".

To date, these reprisal attacks against northern herders have not materialized but there are ominous signs. The interplay of herders' attacks on farming communities and inflammatory rhetoric by ethnic and Christian leaders in the south could spark even more violence. The geographic spread or escalation of the conflicts could put Nigeria's military and other security forces under greater stress, diverting the resources they need for operations against Book Harem in the north east, militants in the Niger Delta and other security challenges (ICG, 2017).

One thing is certain and that is that the conflict being discussed derive its fuel from a type of animal grazing that majority have come to see as trouble shooting. Though seen in some quarters as ordinary conflicts between groups, the grazing induced conflict is dangerously viewed by a large section of the Nigerian population (especially from the southern part of the country) as being politically motivated and targeted at ethnic and religious cleansing against groups from the southern part of the country. This feeling if allowed to explode, could spell doom for the corporate entity called Nigeria. Some have expressed the view that nation ever survives two civil wars. Coming out of a devastating thirty months civil war and presenting contending with the book harem insurgency in the north eastern part of the country, a restive Niger delta and a secession-clamoring south east, it is left to be seen how the country will manage the situation if matters get to its head.

\section{Timeline of Farmers and Herders Clashes in Nigeria from 2000 to 2017}

Attacks by what has lately come to be known as Fulani herdsmen against other Nigerians in general and crop farmers in particular have been with us for quite some time but they have been on the increase in recent times. One BBC report claimed that these clashes have claimed thousands of lives within a period of twenty years BBC (2016). [28] Noted that clashes between different groups of Fulani herders and farmers have killed thousands of people in Nigeria over the past two decades. According to him, information released by the Global Terrorism Index (GTI), (which ranked the Fulani herdsmen as the fourth deadliest terrorist group in the world, after the Islamic State in Iraq and Syria (ISIS), Taliban and al-Shabaab), showed that in 2014 alone, more than 1,200 people lost their lives.

While many have divergent opinions on the remote and immediate causes of these attacks, it has been reported that the Fulani, under an umbrella organization known as the Miyetti Allah Cattle Breeders Association of Nigeria (MACBAN), claim that they are being attacked by gangs from farming communities who steal their cattle and that they are simply defending themselves against such attacks. Recently, the country recorded series of clashes between them and farmers which led to loss of lives and properties and some of those clashes in Nigeria are presented in (Table 1).

Table 1: Chronicle of Herdsmen dastardly activities and killings (2002-2017)

\begin{tabular}{|c|c|c|c|}
\hline $\mathbf{S} / \mathbf{N}$ & Date & Incidence & Place \\
\hline 1 & JAN, 2002 & $\begin{array}{l}30 \text { people were killed in conflicts between farmers and herders } \\
\text { over grazing land in barkinladi local council area of plateau state. }\end{array}$ & Plateau State \\
\hline 2 & Feb, 2003 & $\begin{array}{l}\text { About } 100 \text { people were killed in clashes over the past days } \\
\text { between fulani and the yungar ethnic groups in adamawa state. }\end{array}$ & Adamawa State \\
\hline 3 & May, 2003 & $\begin{array}{c}\text { Herdsmen attacked and burned } 34 \text { farming villages in adamawa } \\
\text { and gombe states which resulted in } 63 \text { dead and over } 500 \text { people } \\
\text { were injured. }\end{array}$ & $\begin{array}{l}\text { Adamawa/ } \\
\text { Gombe States }\end{array}$ \\
\hline 4 & Feb, 2004 & $\begin{array}{l}49 \text { farmers were killed as they flee nomad attacks by nomads in } \\
\text { the farming town of yelwa, plateau state }\end{array}$ & Plateau State \\
\hline 5 & Feb, 2005 & $\begin{array}{l}\text { Dozens of people were killed in adamawa state when fulani } \\
\text { herdsmen alleged to come from chad and niger attacked farming } \\
\text { communities in a dispute over grazing land. }\end{array}$ & Adamawa State \\
\hline 6 & Dec, 2009 & $\begin{array}{l}32 \text { people were killed, scores of houses burned, and several farms } \\
\text { destroyed following clashes between pastoralists and farmers } \\
\text { in nassarawa state. About } 700 \text { pastoralists were sent away from } \\
\text { borno state }\end{array}$ & Nasarawa/and Borno State \\
\hline 7 & March, 2010 & $\begin{array}{l}\text { Fulani herders invaded three villages of Dogo Na Hauwa, Ratsat } \\
\text { and Jeji in Jos South Local Government Area of Plateau State killing } \\
\text { many people including mostly children and women in a barbaric } \\
\text { manner. }\end{array}$ & Plateau State \\
\hline
\end{tabular}




\begin{tabular}{|c|c|c|c|}
\hline 8 & Nov, 2011 & $\begin{array}{l}\text { Fulani/ farmers clash in Kirikasamma Local Government area of } \\
\text { Borno State left one person killed and over } 17 \text { people from the } \\
\text { farmers' side seriously injured. This was triggered when farmers } \\
\text { in the area took measures to protect the perennial destruction of } \\
\text { their yet -to-be harvested farm produce and frequent attacks on } \\
\text { them by the Fulani pastoralists. Conflicts between farmers and } \\
\text { Fulani pastoralists in Benue State, left two soldiers, some } 50 \text { men, } \\
\text { women, and children dead. }\end{array}$ & Borno and Benue State \\
\hline 9 & March, 2012 & $\begin{array}{c}\text { The conflict between Fulani pastoralists and sedentary farmers } \\
\text { in Gwer West Local Government Area of Benue State left over } 30 \\
\text { people dead. }\end{array}$ & Benue State \\
\hline 10 & March, 2012 & $\begin{array}{c}\text { Sixteen people were killed in a clash betwe en Tiv farmers and } \\
\text { Fulani herdsmen in Kadarko community, Giza Local Council of } \\
\text { Nasarawa State. About 5,000 residents fled to safer areas in nearby } \\
\text { towns. }\end{array}$ & Nasarawa State \\
\hline 11 & April, 2012 & $\begin{array}{l}\text { April } 2012 \text { One person was killed, and several others were injured } \\
\text { in a Fulani -Hausa Clash in Sokoto. }\end{array}$ & Sokoto State \\
\hline 12 & May, 2012 & $\begin{array}{l}\text { A clash between farmers and herders in Gwer West area in Benue } \\
\text { State left five people dead, and many others displaced }\end{array}$ & Benue State \\
\hline 13 & June, 2012 & $\begin{array}{l}\text { At least six people were killed, houses burnt, and several } \\
\text { farmlands were destroyed in Ngandum Vill age, Adamawa State as } \\
\text { pastoralists and farmers engaged in a fierce battle. These occurred } \\
\text { after Herdsmen led their cattle into rice fields resulting in the } \\
\text { death of a farmer. }\end{array}$ & Adamawa State \\
\hline 14 & July, 2012 & $\begin{array}{l}\text { About } 200 \text { persons, including a serving federal senator, Gyang } \\
\text { Dantong, were killed in Matse and Kakuru villages during a funeral } \\
\text { for some people killed earlier by suspected Fulani herdsmen. }\end{array}$ & Plateau State \\
\hline 15 & Dec, 2012 & $\begin{array}{l}\text { Clashes between Gbagyi farmers and Fulani nomads near Abuja } \\
\text { left two people dead, five injured, and over 1,500 people displaced } \\
\text { from about } 27 \text { settlements that were destroyed. }\end{array}$ & Plateau State \\
\hline 16 & April 23, 2013 & 10 farmers killed in Mbasenge community, Guma LGA & Benue State \\
\hline 17 & May 7, 2013 & $\begin{array}{c}47 \text { mourners killed in Agatu while burying } 2 \text { policemen killed in } \\
\text { neighboring Nassarawa town }\end{array}$ & Benue State \\
\hline 18 & May 12, 2013 & $\begin{array}{l}83 \text { killed by Fulani herdsmen in the Okpanchenyi and Ekwo } \\
\text { communities of Agatu }\end{array}$ & Benue State \\
\hline 19 & May 14, 2013 & $\begin{array}{l}40 \text { killed as over } 200 \text { herdsmen stormed Ekwo-Okpanchenyi, } \\
\text { Agatu LGA }\end{array}$ & Benue State \\
\hline 20 & June 11, 2013 & $\begin{array}{l}1 \text { killed, by Fulani rubbers. Also, over } 40 \text { cattle belonging to the } \\
\text { Catholic Church Otukpo were led away. A number of people were } \\
\text { injured. Ichama Village, Okpokwu LGA, Benue State. }\end{array}$ & Benue State \\
\hline 21 & July 1, 2013 & 40 people killed Fulani gunmen attacked in Okpanchenyi village. & Benue State \\
\hline 22 & July 5, 2013 & $\begin{array}{l}60 \text { killed following clashes between Tiv farmers and herdsmen in } \\
\text { Nzorov, Guma, and LGA. }\end{array}$ & Benue State \\
\hline 23 & July 28, 2013 & 8 killed as herdsmen invaded 2 villages in Agatu LGA. & Benue State \\
\hline 24 & Sept 29, 2013 & 15 killed in Agatu by Fulani herdsmen & Benue State \\
\hline 25 & Oct 13,2013 & $\begin{array}{l}30 \text { People killed in Oguche and Agatu by suspected Fulani } \\
\text { Herdsmen }\end{array}$ & Benue State \\
\hline 26 & Nov 7, 2013 & $\begin{array}{c}7 \text { killed, 6,000+ displaced when attackers struck Ikpele \& } \\
\text { Okpopolo communities, Agatu LGA. }\end{array}$ & \\
\hline 27 & Nov 9, 2013 & 36 killed and 7 villages overrun in Agatu LGA. & \\
\hline 28 & Nov 20, 2013 & $\begin{array}{l}22 \text { killed and lots of properties destroyed in an attack in Guma } \\
\text { LGA. }\end{array}$ & \\
\hline
\end{tabular}




\begin{tabular}{|c|c|c|c|}
\hline 29 & Jan 20, 2014 & $\begin{array}{c}5 \text { soldiers and } 7 \text { civilians gunned down in an attack, in Agatu LGA } \\
\text { and } 3 \text { killed in attack in Adeke Village }\end{array}$ & \\
\hline 30 & Feb 20-21, 2014 & $\begin{array}{c}35 \text { killed, 80,000 displaced, } 6 \text { villages sacked following an attack in } \\
\text { Gwer West LGA }\end{array}$ & \\
\hline 31 & Feb 24, 2014 & $\begin{array}{l}8 \text { killed following an attack on a Tiv community along Naka road, } \\
\text { Makurdi }\end{array}$ & Benue State \\
\hline 32 & Mar 6, 2014 & 30 killed, 6 villages sacked in Katsina/Ala and Logo LGAs. & \\
\hline 33 & March 10, 2014 & $\begin{array}{l}\text { The convoy of ex-Governor Suswam attacked at Umenger. He } \\
\text { managed to escape. }\end{array}$ & \\
\hline 34 & Maech 12, 2014 & $\begin{array}{l}28 \text { killed in a raid on Ukpam, in Guma LGA. Yam barns and farms } \\
\text { burnt and another } 22 \text { slaughtered in an attack on Suswam's village, } \\
\text { Logo LGA. The entire village sacked. }\end{array}$ & \\
\hline 35 & March 25, 2014 & $\begin{array}{c}\text { More than } 60 \text { killed and many houses burnt, prompting Gov. } \\
\text { Suswan to seek help from the army. }\end{array}$ & Benue State \\
\hline 36 & March 27, 2014 & $\begin{array}{l}\text { About } 55 \text { were killed at Gbajimba with many houses destroyed. } \\
\text { over 52,000 internally displaced people at camp established by the } \\
\text { Catholic Diocese of Makurdi. }\end{array}$ & Benue State \\
\hline 37 & March 29, 2014 & $\begin{array}{l}\text { More than } 200 \text { villagers and a few herdsmen in army camouflage } \\
\text { killed. } 3 \text { Villages (Sankwai, Takum, and Marchek) about } 250 \\
\text { kilometers South of Kaduna metropolis destroyed. }\end{array}$ & Kaduna State \\
\hline 38 & April 12, 2014 & 2 were killed in Gwer West L.G.A & Benue State \\
\hline 39 & Sept 10, 2014 & Scores dead when herdsmen attacked 5 villages in Ogbadibo LGA. & \\
\hline 40 & Dec 14,2014 & 10 killed in Benue State by Fulani Herds men. & \\
\hline 41 & March 5, 2015 & $\begin{array}{l}10 \text { people were killed with more than } 100 \text { houses burnt in Riyan } \\
\text { L.G.A. }\end{array}$ & Plateau State \\
\hline 42 & March, 2015 & $\begin{array}{l}\text { Farmer's hand was cut off; his sibling was raped and farmland } \\
\text { destroyed. }\end{array}$ & Oyo Sate \\
\hline 43 & May 24, 2015 & $\begin{array}{c}5 \text { days to the end of Governor Suswam's administration in May } \\
2015 \text { over } 100 \text { farmers and their family members were killed in } \\
\text { villages and refugee camps located in Ukura, Per, Gafa and Tse } \\
\text {-Gusa LGAs of the State }\end{array}$ & Benue State \\
\hline 44 & Apr 12, 2016 & $\begin{array}{l}15 \text { people were killed as the Fulani herdsmen attacked two villages } \\
\text { in Gashaka Local Government Area of Taraba State }\end{array}$ & Taraba State \\
\hline 45 & April 19, 2016 & $\begin{array}{l}\text { Twenty-five Local Government Areas in Delta State protested } \\
\text { on the Benin -Asaba Expressway, the alleged killing of about } 23 \\
\text { persons by herdsmen. }\end{array}$ & Delta State \\
\hline 46 & April 25, 2016 & $\begin{array}{l}\text { Fulani herdsmen attacked Ukpabi Nimbo in Uzo - Uwani Local } \\
\text { Government Area of Enugu State and about } 40 \text { people were killed }\end{array}$ & Enugu State \\
\hline 47 & June, 2016 & $\begin{array}{l}\text { A } 46 \text { year old renowned farmer was shot by gunmen suspected to } \\
\text { be Fulani herdsmen in Ossissa community in Ndokwa East Local } \\
\text { Government Area }\end{array}$ & Delta State \\
\hline 48 & August, 2016 & $\begin{array}{l}\text { Herdsmen reportedly numbering over 50, armed with machetes } \\
\text { disrupted the peace of Ndiagu community of Attakwu, Akegbe- } \\
\text { Ugwu in NkanuWest Local Government Area. A Catholic } \\
\text { Seminarian, Lazarus Nwafor killed and severely injured four } \\
\text { members of the Ogbodo Nwarum family }\end{array}$ & Enugu State \\
\hline 49 & Oct., 2016 & $\begin{array}{l}\text { Armed Fulani herdsmen opened fire on villagers who attempted } \\
\text { to stop their cattle from grazing their farmlands in Umuekune } \\
\text { village of Irete community in Owerri West Local Government Area. } \\
\text { Several people were wounded in the ensuing stampede with two of } \\
\text { the injured on danger list }\end{array}$ & Imo State \\
\hline 50 & Jan. 17, 2017 & $\begin{array}{l}\text { Herdsmen opened fire in Samaru Kataf market, killing } 3 \text { persons } \\
\text { and injuring } 5 \text { in Zango-Kataf Local Council Area. }\end{array}$ & Kaduna State \\
\hline
\end{tabular}




\begin{tabular}{|c|c|c|c|}
\hline 51 & Jan., 2017 & $\begin{array}{l}\text { A fresh crisis between Fulani herdsmen and Idoma farmers at } \\
\text { Okpokwu Local Government Area, left not less than five people } \\
\text { dead and several others injured }\end{array}$ & Benue State \\
\hline 52 & Jan. 24, 2017 & $\begin{array}{l}\text { Grazing of cattle and destruction of farmlands led to a bloody fight } \\
\text { in which } 2 \text { herdsmen and } 13 \text { villagers (a total of } 15 \text { persons were } \\
\text { killed in Ipiga village in Ohimini LGA. }\end{array}$ & Benue State \\
\hline 53 & Jan. 24, 2017 & $\begin{array}{l}5 \text { students of the College of Education, Gidan Waya in a commercial } \\
\text { car taking students to school from Kafanchan were waylaid and } \\
\text { shot dead by alleged herdsmen in } \\
\text { Jema'a LGA. }\end{array}$ & Kaduna State \\
\hline 54 & Jan., 2017 & $\begin{array}{c}\text { Fulani herdsmen attacked Rafin Gone and Gbagyi villages in Bosso } \\
\text { Local Government Area. At least 6,000 persons displaced and } \\
\text { nine people killed, including a police Inspector and an Assistant } \\
\text { Superintendent Officer of the Nigeria Security and Civil Defense } \\
\text { Corps }\end{array}$ & Niger State. \\
\hline 55 & Feb. 10, 2017 & $\begin{array}{c}8 \text { people were confirmed dead in clashes between community } \\
\text { members and suspected herdsmen in } \\
\text { Rukumawa Tsafe LGA, }\end{array}$ & Zamfara State \\
\hline 56 & Feb. 21, 2017 & $\begin{array}{l}\text { About } 21 \text { people were killed when Fulani herdsmen launched } \\
\text { attacks on four communities in Southern Kaduna, }\end{array}$ & Kaduna State \\
\hline 57 & Mar 2, 2017 & $\begin{array}{c}\text { No fewer than } 10 \text { persons were killed in renewed hostilities } \\
\text { between herdsmen and farmers in Mbahimin community in Gwer } \\
\text { East LGA, }\end{array}$ & Benue State \\
\hline 58 & Mar. 6, 2017 & $\begin{array}{l}6 \text { persons died in clash between suspected herdsmen and } \\
\text { residents of Omumu community in Ika South LGA, }\end{array}$ & Delta State \\
\hline 59 & Mar 11, 2017 & $\begin{array}{c}7 \text { people were killed in Mkgovur village, a Tiv Community in } \\
\text { Buruku L.G.A. }\end{array}$ & Benue State \\
\hline 60 & Mar, 14, 2017 & $\begin{array}{c}1 \text { person was killed and several others injured in clashes between } \\
\text { herdsmen and the people of } \\
\text { Umuobasikwu, Ozuitem in Bende L.G.A. }\end{array}$ & Abia State \\
\hline 61 & Mar. 27, 2018 & $\begin{array}{c}1 \text { killed, } 1 \text { injured, women raped in their farms in a suspected } \\
\text { Herdsmen attack in Adam Village, Kwande LGA. }\end{array}$ & Benue State \\
\hline 62 & Mar. 28, 2018 & $\begin{array}{c}3 \text { persons were killed while six others sustained injuries in an } \\
\text { attack by suspected herdsmen in } \\
\text { Emuhu community in Ika South LGA, }\end{array}$ & Delta State \\
\hline 63 & Apr 1, 2017 & $\begin{array}{c}\text { Suspected Fulani herdsmen killed no fewer than } 10 \text { persons in } \\
\text { a raid on Obio Usiere village in Eniong Abatim community, } \\
\text { Odukpani LGA, }\end{array}$ & Cross River State \\
\hline 64 & May 8, 2017 & $\begin{array}{l}3 \text { persons were killed. In clash between herdsmen and farmers in } \\
\text { Tse-Akaa village, Ugondo Mbamar District of Logo LGA, }\end{array}$ & Benue State \\
\hline 65 & May 12, 2017 & $\begin{array}{l}\text { Suspected herdsmen beheaded a commercial motorcycle rider and } \\
\text { six farmers who worked with Ugo Farm. They were ambushed on } \\
\text { their way home to Ossissa community in Ndokwa East LGA, }\end{array}$ & Delta State \\
\hline 66 & May. 18, 2017 & $\begin{array}{c}2 \text { persons lost their lives in a suspected herdsmen attack in Afam } \\
\text { Uku, Oyigbo LGA, }\end{array}$ & Rivers State \\
\hline 67 & May 22, 2017 & $\begin{array}{l}2 \text { people were killed and } 1 \text { was wounded and lots of persons } \\
\text { sacked from their farmlands. Crops worth millions of naira were } \\
\text { destroyed while herdsmen entered farmlands raped two women } \\
\text { and strangled them to death in Ewu community, Esan Central LGA, }\end{array}$ & Edo State \\
\hline 68 & Dec.31 17/Jan. 1, 18 & $\begin{array}{l}\text { Suspected Fulani herdsmen-turned gunmen also visited several } \\
\text { communities in two LGAs (Logo and Guma) and killed over fifty } \\
\text { (50) villagers, including women and children. }\end{array}$ & Benue State \\
\hline
\end{tabular}




\section{From Open Grazing to Grazing Reserves and Cattle Colony}

It is important to once again revisit the concept of open grazing so as to stand on that to fully appreciate the meaning of a grazing reserves and cattle colony as people in some quarters have recently advocated. Open grazing is the age old practice of roaming ruminant animals in open fields, plains and bushes in search of pasture or foliage. It has been practiced in Nigeria for centuries and continues to be practiced today but the hazards associated with it and the crisis it is currently generating has compelled the government at some point in time to consider the adoption of other methods of ruminant livestock keeping. [39] identified climate change-induced migration from the north to the south, the growth of agro-pastoralism, the expansion of farming on pastures, the invasion of farmlands by cattle, assault on non-fulani women by herders, blockage of stock routes and water points, freshwater scarcity, burning of rangelands, cattle theft, inadequate animal health-care and disease control, overgrazing on fallow lands, defecation on streams and roads by cattle, extensive sedentarization, ineffective coping strategies, ethnic stereotyping, and the breakdown of conflict intervention mechanisms as some of the ills associated with the open grazing system. These ills compelled government in the past to embark on the search for alternative ways of animal grazing other than the open grazing system. That search resulted in the creation of grazing reserves and ranches in parts of the country decades ago. The question that readily comes to mind now is, 'what is a grazing reserve'?

In this study a grazing reserve is defined as an area set aside for the use of pastoralists and their herds. The concept/project involved the gusseting, demarcating and developing an area as a grazing area by the provision of the basic needs of herdsmen and their animals such as pasture, feed supplements, water resources (boreholes and dams, marketing outlets and other infrastructure). [4] Listed some of the gains from the grazing reserves as easing seasonal migration, improving the quality of herds, multiplying outlet for bovine product, and enhancing access to extension and social services. A grazing reserve also encourages the uniform deployment of the cattle. Grazing reserves resemble group ranches in that both consist of clearly defined areas of rangeland which provides grazing for determined herds of livestock.

The stated purpose of grazing reserves is the settlement of 'nomadic' pastoralists because they offer security of tenure as an inducement to sedentarization through the provision of land for grazing and permanent water. The reason for grazing reserves, according to Suleiman (1986) was to promote settlement or 'sedentarization' of nomadic pastoralists with a view to reducing mobility of both people and their livestock and opportunities for farmer-pastoralist encounters. The objective was to utilize an area to demonstrate to the pastoralists that a sustained high level of development can be achieved by combining (free) range management techniques with modern management practices [11]. It was envisaged that livestock improvement efforts (e.g. stock upgrading, cross-breeding and restocking) would be promoted through this method. By the envisaged adoption of these modern production methods, traditional sector production and the economic well-being of the producers are expected to improve. Another long-term goal of the policy was to change nomadic pastoralists to settled and semi-settled agro-pastoralists and ultimately produce mixed farmers (mixed farming is a system of farming in which crop growing is combined with keeping livestock for profit).

As a result of the problems associated with open grazing as practiced in Nigeria then and to the tap the envisaged gains inherent in the grazing reserve philosophy, attempts were made even in pre colonial times to demarcate areas for animal herding. Ingawa, tarawali and kaufmann (1989) noted that the practice of preserving land for exclusive use by livestock existed prior to colonial times. Allocation of grazing grounds to pastoralists around towns and villages for use, particularly during the farming season were socially sanctioned.

However, $[41,16]$ noted that the first of such attempt in post colonial nigeria officially came with the grazing reserve act of 1964 which was aimed at granting grazing lands to pastoralists so as to reduce farmer-pastoralist clashes, improve productivity by encouraging sedentarization and to improve social amenities in such settlements. Among such reserves established at the time were the Kachia grazing reserves in present day Kaduna state and the obudu cattle ranch in today's cross river state. The attempt was a response to the problem of alienation of grazing lands increasingly being faced by the pastoral population at the time. In a broader framework, the step was also taken as one of the policy measures to address some of the problems confronting livestock development in Nigeria.

By 1980, 2.3 million hectares of land were already acquired as grazing reserves by the northern state governments, constituting $10 \%$ of the total 22 million hectares envisaged under the third national development plan (ministry of agriculture, 1981). However, [27] argued that the policy was poorly implemented and because of that, little was achieved as most of the 415 grazing reserves established by the northern regional government from the middle of 1960 have since been lost. High compensation levels for acquisition of grazing reserves recommended by the federal land act of 1978 was indicated as a major cause for the poor implementation of the grazing reserves policy. Only 114 of such reserves were formally documented or demarcated because government failed to back the agreements with legislation guaranteeing exclusive usage or take active measures to prevent encroachment. The rest succumbed to pressure from rapid population growth and the associated demand for farmland, were overrun by urban and other infrastructure, or appropriated by private commercial interests. In some specific cases, none of the pastoral fulani households settled on the reserves were previously nomadic, having been residents around the crop farming villages prior to the establishment of the grazing reserves. With the northern region's division into nineteen states, grazing reserves straddling two or more state jurisdictions lost collective management. The cumulative effect has been to significantly reduce the availability of designated grazing reserves; forcing herders to seek pasture elsewhere (icg, 2017). 
Another attempt at moving on with the grazing reserve policy was made through the instrumentality of the national agricultural policy of 1988 , which sought to allocate $10 \%$ of Nigeria's landmass to grazing reserves. Regrettably, the nigerian centre for international environmental law (ciel 2006), cited in [27] observed that only $2.82 \%$ of the country's landmass was actually acquired for grazing purposes under the policy.

In 2011, another effort was initiated to address the problem by coming up with a bill titled, 'the national grazing route and reserve commission law, 2011'. The proposed law which aims at establishing grazing routes and grazing reserves for pastoralists became stalled soon after it was introduced in the national assembly.

Going by the increased tempo of attacks by Fulani herdsmen in recent times, the need for a law to control the situation became apparently urgent. Listed below are some bills which, according to oyeyipo and James (2016), were recently presented to the national assembly by lawmakers to solve the problem. These proposed laws include:

A. A senator in the Seventh Senate proposed a bill for the enactment of an Act to provide for the Establishment of National Grazing Routes and Reserves with a Commission to manage them (Kumolu, 2014). The commission was to earmark animal grazing routes and to prevent herdsmenfarmer clashes as well as cattle rustling in Nigeria. However, the bill was rejected by Senate.

B. A bill titled 'National Grazing Reserve (Establishment) Bill 2016' seeking to establish a National Grazing Reserve Commission for the establishment of at least one cattle reserve in each state of the federation was proposed but did not scale through.

C. A bill entitled 'The National Grazing Routes and Reserve (Establishment) Bill' (2012) was proposed to establish grazing reserves, routes and a commission to manage them and were to crystallize into ranches later. The bill made provisions for representatives from the thirty-six states of the federation and the Federal CapitalTerritory (FCT). It also failed.

Many of the bills did not succeed primarily due to suspicions of a desire to further Fulani expansionist motives by requiring the establishment of grazing reserves in each state of the federation. This was because states would be obliged to cede part of their lands for the purpose of establishing such grazing reserves. Expectedly, opposition to the bills arose mostly from representatives of southern and middle belt states that had been at the receiving end of herdsmen's violence and attacks. The bill's proposal to compensate land ceded for the grazing reserves and ranches was not enough to see the bill through, being considered to have political motives or undertones.

As has been argued, the bill failed...as the senators were divided over whether the federal government was constitutionally empowered to create grazing reserves and stock routes in any state of the federation. The inability of the government to promulgate a law establishing grazing reserves raises doubt on the government's commitment to finding a lasting solution to the conflict.

Following this failure by the federal government and the continuing skirmishes between herders and local farmers in various states of the federation, some state governments have taken the bold step to ban open grazing in their respective states. Among such states and there anti grazing law or bills as put together by Owegie (2017) are:

\section{Review of empirical Literature}

Animal herding, grazing or pastoralism and its implication to sustainable development in Nigeria have remained at the front burners of the nation's discourse especially in recent times. Scholars, for instance, have conducted numerous studies on that and have continued to do so from different perspectives. A review of some of the studies will suffice here.

In one study titled, Climate Change and Conflicts in Nigeria: A Theoretical and Empirical Examination of the Worsening Incidence of Conflict between Fulani

Herdsmen and Farmers in Northern Nigeria, [32] examined the theoretical and empirical nexus between climate change and conflicts in Nigeria. More fundamentally, it showed how climate change accounts for the worsening incidence of conflict between herdsmen and farmers in northern Nigeria. The study extensively made use of the eco-violence theory in its analysis and at the end argued that much as it believes that the immediate cause of Fulani herdsmen and farmers' conflict in northern Nigeria is natural resource scarcity, the remote cause is climate change which has, through drought and desertification, led to the worsening incidence of natural resource scarcity which exacerbates conflicts between the two groups. The scholars posited that since climate change has come to stay, it is important for government to put more machinery on ground (particularly in the north because over 70 percent of the nation's food crops comes from the region) by encouraging climate change mitigation and adaptation. Furthermore, climatologic research should be enhanced to combat desert encroachment, and in the long run reduce migration and its associated conflicts.

Similarly,[18] conducted a study, to discover Fulani Cattle Productivity and Management in the Kachia Grazing Reserve (KGR), Kaduna State, Nigeria. This study examined productivity and management of cattle belonging to livestock keepers within the reserve before and after a mass immigration event when 3,000 refugees moved into the reserve with their cattle to escape inter-community violence during May, 2011.

In another study titled Pattern and Impact of Conflicts between Farmers and Herders in Riyom Local Government Area of Plateau State, Nigeria, [19] attempted to examine the pattern and impact of conflicts between farmers and herders in Riyom local government area of Plateau State from 2011 to 2016. The study also assessed the effectiveness of measures employed for managing the conflicts. It employed a cross sectional survey method and a multi-stage purposive sampling method. Findings revealed that herders-farmers conflict is prevalent in Riyom 
Local government Area and has impacted negatively on the socio-economic livelihood of the people. It argued that farmersherder's conflicts in Riyom are caused by a combination of factors such as crops damage by cattle, land encroachment, encroachment on grazing reserves, lack of access to water point and pollution of water points, killing of stray cattle, cattle rustling, indiscriminate bush burning and disregard to rules and regulations. It recommended among many, the enactment of a law to ban open grazing and a law to establish enclosed grazing (ranches), arrest and prosecution of offenders, improved training for the police and other law enforcement agencies, the involvement of traditional rulers who are the custodian of culture in conflict resolution, enhanced public information and education on the need for citizens to respect and obey the law and engage in dialogue to promote peaceful and harmonious co-existence.

[2] Carried out another study titled, 'Climate Change and Pastoral Conflicts in the Middle Belt and South-East Nigeria: Implications on Human Resources of the Regions'. The study examined the relationship between climate change and pastoral conflicts as well as their effects on human resources of both the middle belt and south eastern Nigeria. It is ex-post-factor in nature and thus relied heavily on literature with qualitative data and descriptive method of analysis. In the main, Deprivation, Frustration and Aggression theory was employed to anchor the study. At the end, the study revealed that pastoralists migrate due largely to extreme and unfavorable weather conditions occasioned by climate change. The paper noted that the strength of a nation lies in her resources. However, pastoral conflicts occasioned by climate change has had a far reaching negative consequences on resources of these regions, ranging from waste to absolute destruction and depletion of both human and material resources. The paper recommended that active and sincere government intervention through the establishment of grazing corridors or ranches in the regions, funding of research and development and establishment of regulatory frame work will help stem the tide.

[36] Conducted another study on, Nomads against Natives: A Political Ecology of Herder/Farmer Conflicts in Nakazawa State, Nigeria. The method of the study was qualitative and exploratory. Data were generated from primary and secondary sources. The primary data were sourced through what they prefer to call 'study chat' with select informants, most of whom were students of Federal University, Labia, and Nigeria, where one of the researchers teaches. Secondary data were elicited from library and official (government) sources. In this regard, books, journals, dailies and periodicals, internet materials, as well as relevant official records were explored with a view to eliciting useful information. This method of analysis for the study follows the pattern of descriptive analysis. The study posits that the phenomenon of herder/farmer conflict in Nakazawa State typifies what is known as resource conflict in contemporary development literature. This thrives in an atmosphere of ecological scarcity and competition, as well as livelihood crisis. The problem has been accentuated by the global trend of climate change which has led to the shrinking of ecological space and resources, leading to intense pressure on, and competition for, the available resources. The spiraling migration of pastoralists from the far north towards the central part of Nigeria has resulted in a sort of dialectical relations between the Fulani herdsmen and the settled native farmers. As the study observed in the case of Nakazawa State, this situation has been complicated by the rising incidence of livelihood insecurity among the farming and herding communities as a result of the dwindling ecological fortunes of the region. This scenario has led to desperate, violent struggles for access to and control of scarce ecological space and resources, a situation that has engendered dire humanitarian, social, socioeconomic and economic consequences. The fierce and often virulent nature of these struggles, have found expression in a vicious circle of violence and mutual vendetta.

Imo (2017) examined the demographic implications resulting from nomadic herdsmen and farmers clashes in Nigeria. Relevant published texts across the country and the Malthusian theory provided the leverage for the study. It revealed that the country's population is dynamic and growing at a very rapid rate compared to land that is relatively static which constitutes the most important cause of pressure and demand for food resources. The study discovered that this scenario has, time without number, thrown up tribal, ethnic, regional, religious and political sentiments that threaten the corporate existence of Nigeria and recommended, as a solution, that government should ensure that those involved in the allocation of land for farming should imbibe responsibility and not allocate along cattle routes or on grazing lands to avoid encroachment by nomadic herdsmen. This will enhance productivity and achievement of Sustainable Development Goals No 2, and 6, which emphasizes the need to adequately achieve food security and sustainable management of resources for the teaming Nigeria population.

In another study titled Sustainable Agricultural Practices and its Determinants in South-East, Nigeria and carried out by Mgbada, Ohajianya and Nzeh, (2016), the study used the multi-stage sampling technique in sample selection and at the end, contended that the determinants of sustainable agriculture practice level of farmers were age, level of education, farm size, household size, annual income, cost of labor, cost of fertilizer, amount of family labor used, climate change variables, availability of organic manure, access to credit, and social organization membership. Consequent upon the findings of this study, it suggested the need to improve on the sustainable agricultural practice level of farmers in South-East, Nigeria through extension education so as to achieve food security and conserve the resource base. This should be intensified and geared towards making farmers to become more aware and understand the consequences of use of more external inputs on their resource base, and the inherent benefits associated with use of more internal inputs in food production.

Further Study titled, 'Challenges of Herdsmen-Farmers' Conflict in Livestock Production in Nigeria: Experience of Pastoralists in Kogi State, Nigeria, conducted by [17], examined the challenges faced by pastoralists in conflict with farming communities in Kogi State, Nigeria. The study used survey method to discover that herding was mainly done for prestige 
and commercial purposes with average farm size of 240 cattle. The research further discovered that conflicts between pastoralists and crop farmers were caused by socio-economic, security, production practices and institution related factors. Consequently, pastoralists had the problems of insecurity of human and animal lives, displacement and economic losses leading to poor productivity. It recommended that all stakeholders (government, nongovernmental organizations, extension agencies, rural institutions among others) should intensify efforts to build cooperative and peaceful coexistence between farmers and pastoralists through public enlightenment, education and campaign in agrarian communities. Government and ngos should promptly intervene with aids/compensation to reduce vulnerability, persistence and further spread of conflict of pastoralist-farmer conflict in communities.

Also relying on the belief that crops and livestock production in Nigeria are not mutually exclusive, [8] conducted a study on 'Small-Scale Farmer's Perception on the Impact of Grazing Livestock Animals on Crop Production in Abuja, Nigeria. The study used multi stage sampling technique while semi structured questionnaire was used for data collection. A total of Three Hundred and Eighty Four (384) small-scale crop farmers were randomly interviewed in four agricultural zones of central, eastern, northern and western zones of the city. Data generated in the study were analyzed using two-way factorial analysis of variance (ANOVA) and mean separation was done at 5\% probability level. Results revealed that there was significant difference in the perceived impact of grazing livestock animals on crop production. The mean responses indicated that the impact of cattle on crop production was perceived to be serious and it was significantly higher than the impacts of goat, sheep and domestic fowls. The implication of this is that cattle were the most destructive livestock animals while domestic fowls were the least. At the zonal level, results revealed that the crop farmers in the eastern and western agricultural zones of Abuja felt the impact of the grazing animals more than crop farmers in the other two zones.

Based on the results, the study recommended that government should map out grazing routes and/or educate and encourage the livestock farmers to adopt intensive system of management to minimize clashes and damages that occure.

Another study conducted by [40] and titled, Prevalence of Herdsmen and Farmers Conflict in Nigeria was also reviewed. The study, which was anchored on the frustration-aggression and conflict theories, set out to examine the prevalence of herdsmen and farmers conflict in Nigeria. Data for the study were extracted from secondary sources like journals, textbooks, newspapers and online organizational publications. Evidences indicated that herdsmen-farmers conflict is prevalent in the country. It also showed that some of the factors that usually led to clashes were limited or unavailability of sufficient resources like grazing fields, farm lands, destruction or grazing on crops, longstanding disagreements, lack of access to farm or grazing fields and scarcity of fresh water. Consequently, loss of human and animal lives, destruction of crops and properties, displacement of persons and animals, distrust between herdsmen and farmers, rising anti-Fulani sentiment and breakdown of peaceful relationship with many communities in some parts of the country were amongst the gross effects of the conflict. However, the study concluded that until this issue is amicably resolved and absolute cooperation among the conflicting parties enhanced; food and national security would continue to be threatened. Therefore, the study recommended amongst others that government should establish cattle grazing fields in the six geo-political zones of the country and out-law open or everywhere grazing of cattle. This must be done through due consultation, dialogue or appeal to some aggrieved regions of the country which may oppose or resist the move. Poor water management practice in the country should be improved by the Federal Ministry of Water Resources. This is in view of the fact that climate change cum water shortage and drought are the major reasons herdsmen are migrating southward in search of fresh water and grass for their cattle.

In a similar study titled Anti-Grazing Policy and Conflict Resolution between Fulani Herdsmen and Farmers in Ekiti State, [34], assessed the Anti-Grazing Policy and Conflict Resolution between Fulani herdsmen and Farmers in Ekiti State. The incessant conflicts between Fulani herdsmen and farmers in Nigeria especially the Iola attack where two people were killed on 20th and the One-Ado, Ekiti State attack on 21st May, 2016, prompted the government to enact an Anti-grazing law in Ekiti State. The objective of the study was to establish the role of antigrazing policy in conflict resolution between Fulani herdsmen and farmers in Ekiti State. Qualitative approach, which focuses on the explanation of subjective perspectives, processes and contextual meanings, was employed for the study. Primary and secondary data sources were used to generate data for the study. Purposive sampling method was used to draw the 22 interview respondents. Both data from interview and secondary sources were analyzed qualitatively. The study revealed that the Ekiti State Government passed into Law the Anti Grazing Bill, 2016 to resolve various conflicts between Fulani herdsmen and Farmers in Ekiti State. It also revealed that the Government set up the Ekiti Anti-Grazing Enforcement Marshal to implement the law. The State government partners with the sixteen (16) Local Government Councils in the State to allocate land to herdsmen for cattle grazing. It was established that the Government also collaborates with the herdsmen Association in Ekiti State to maintain peaceful implementation of the law. It also discovered that the Anti-Grazing Policy has succeeded in resolving conflicts between Fulani herdsmen and farmers in Ekiti State. The researchers therefore recommended the creation of grazing zones; private ownership of ranches; security of borders; training of Ekiti State Grazing Marshals and proper monitoring of their operations.

\section{Methodology}

The study adopted ex-post facto research method. Ex postfacto is a typology of descriptive research which the independent variable(s) have already occurred and in which an investigation occurred and investigator starts with the observation of dependent variable(s) and then study the independent variable 
in retrospect for their possible relationship to an effect on the dependent variable(s). Accordingly, while primary data were generated from a few opinion leaders in the society through a purposive sampling technique to complement secondary data, the study adopted a qualitative rather than a quantitative approach.

\section{Method of data analysis}

In view of the fact that this study relied heavily on secondary data, all works used were content analyzed with a view to determining whether they support or vary with the study's stated objectives and the degree of such support or variation.

\section{Conclusion and Recommendations}

A cattle breeding is a private business and not that of government, therefore allowing cattle's to stray is a primitive practice. Agricultural produce contribute in great measure to GDP and therefore any attempt to frustrate farmers in Nigeria will spell doom to sustainable development. As a panacea to this problem, it is the position of the paper that the Government of Nigeria should as a matter of urgency do the following:

1. There should be effective regulation of grazing and farming activities in Nigeria through efficient land-use laws/ legislations and administration;

2. The Government should create grazing reserves and dedicated grazing routes in order to solve the issue of herd's encroachment on farmlands.

3. The Myetti Allah, the Cattle Breeders Association in Nigeria should interface with the farmers for peaceful coexistence. The Association should be ready to defray the cost of crops damaged by their cattle.

4. Pastoralists buy lands and build ranches in lieu of the obnoxious proposal of cattle colony since cattle rearing is a private business.

\section{References}

1. Abass I M. No Retreat No Surrender Conflict for Survival between the Fulani Pastoralists and Farmers in Northern Nigeria. European Scientific Journal. 2012:8(1)331-346.

2. Abugu S O. and Onuba C O. Climate Change and Pastoral Conflicts in the Middle Belt and Southeast, Nigeria: Implications on Human Resources of the Region. European Center for Research Training and Development, UK 2015:3(5)44-51.

3. Adejumo A V and Adejumo 0 0. Prospect for Achieving Sustainable Development through the Millennium Development Goals in Nigeria. European Journal of Sustainable. 2014:3(1)33-46.Doi:10.14207/ ejsd.2014.v3n1p33

4. Adeoye N O. Land Use Conflict between Farmers and Herdsmen in parts of Kano, Yobe and Borno States of Nigeria: Nomads Viewpoint. Ghana Journal of Geography, 2017:9(1)127-151.

5. Adisa R S. Land Use Conflicts between Farmers and Herdsmen Implications for Agricultural and Rural Development in Nigeria. Rural Development-Contemporary Issues and Practices (Ed) Shanghai, InTech. 2012 Doi: 10.5772/45787
6. Agbedo 0. Tracking Endless Fulani Herdsmen/Farmers Clashes, Sunday Sun Newspaper, September 2016:4: 30.

7. Ajaero C K, Mozie A T, Okeke I C, Okpanachi J P and Onyishi C. The Drought-Migration Nexus:Implications for Social-Ecological Conflicts in Nigeria. Mediterranean Journal of Social Sciences. 2015:6(251)470478.Doi: 10.5901/mjss.2015.v6n2s1p470

8. Ajah J. Small Scale Farmers Perception on the Impact of Grazing Livestock Animals on Crop Production in Abuja, Nigeria, Trends in Agricultural Economics, 2012:5,115-123.Doi:10.3923/ tae.2012.115.123

9. Akujobi C T, Ebitari S and Amuzie H O. Arable Land Resource Conflict in Nigeria. Journal of Applied Science and Development. 2016:72(1)3965.

10. Alhassan U B. Herdsmen and Farmers Conflicts in North Eastern Nigeria: Causes, Repercussions and Resolutions. Academic Journal of Interdisciplinary Studies, 2013:2(5)129-139.Doi:10.5901/ajis.2013. v2n5p129

11. Awogbade M O. Grazing Reserves in Nigeria. Nomadic Peoples, 1987:23:18-30.

12. Awogbade M. Making Sense of Nigeria's Fulani-Farmer Conflict, 8 May,2016:2004.

13. Blench R. Conflict between Pastoralists and Cultivators in Nigeria: Review paper prepared for DFID, Nigeria. 2010:1-14.

14. Brown I A. Assessing Eco-Scarcity as a Cause of the Outbreak of Conflict in Darfur: A Remote Sensing Approach. International Journal of Remote Sensing, 2010:31(10),2513-2520.Doi:10.1080/01431161003674592

15. Chambers J D and Mingay G E. The Agricultural Revolution: 1966:17591880, New York, Schocken Books.

16. Coleman J S. Nigeria: Background to Nationalism, Berkeley, University of California Press. 1958:1965

17. Dimelu M U, Salifu D U, Enwelu A I and Igbokwe E M. Challenges of Herdsmen-Farmers Conflict in Livestock Production in Nigeria. Experience of Pastoralists in Kogi State, Nigeria. 2017:12(8)642-650. Doi: 10.5897/AJAR2016.11740

18. Ducrotoy M J, Majekodunmi A O, Shaw A P M, Bagulo H, Musa U B, Bertu W J, Gusi A M, Ocholi R A, Bryssinck W and Welburn S C. Fulani Cattle Productivity and Management in the Kachia Grazing Reserve, Nigeria. Pastoralism: Research Policy and Practice, 2016:6(25)1-19. Doi:10.1186/s13570-016-0072-y

19. Eje T I, Angai I A, Abdulahi Y B, Eje P O, Wudaba L E, and Ishaku N. Pattern and Impact of Conflicts between Farmers and Herders in Riyom L.G.A. of Plateau State, Nigeria. The International Journal of Humanities and Social Sciences, 2017:5(10)256-271.

20. Ekperiewe M C, Olatayo T O, Egbetokun A A. Human Capital and Sustainable Development in Nigeria: How can Economic Growth Suffice Environmental Degradation? Economics Discussion Papers, NO 2017-29.

21.Erhun M O. A Sustainable Approach to Economic Development in Nigeria: ALegal Perspective. Journal of Economics and Sustainable Development, 2015:6(14)1-6.

22. Ezeonwuka I F and Igwe A U. Emerging Challenges in Nigeria's National Security in the Twenty-First Century: The Fulani Herdsmen Menace. Asian Journal of Multidisciplinary Studies, 2016:4(5)204215. 
23. Fayinka F A. Food Security in Nigeria: Challenges under a Democratic Dispensation, Paper Presented at the 9th ARMTI Annual Lecture, March, 2004.

24.Gberevbie D, Joshua S, Excellence-Oluyo N, Oyeyemi A. Accountability for Sustainable Development and the Challenges of Leadership in Nigeria, 1999-2015. SAGE Open. 2017; 1-10. DOI: $10.1177 / 2158244017742951$

25.Gefu J 0, Are K. Conflict in Common Property Resource Use: Experiences from an Irrigation Project. Paper prepared for the $9^{\text {th }}$ Biennial Conference of the International Association for the study of Common Property.

26. Homer-Dixon T.F. Environment, Scarcity and Violence. Princeton. Princeton University Press. 2001;

27. Ibrahim M, Abdurrahman BI, Umar MB. An Assessmentb of Farmer Pastoralist Conflict in Nigeria Using GIS. International Journal of Engineering and Science Invention. 2015; 4(7), 23-33.

28. Idowu AO. URBAN VIOLENCE DIMENSION IN NIGERIA: FARMERS AND HERDERS ONSLAUGHT. AGATHOS. 2017; 8(1): (14): 187-206.

29. Idowu AJ, Okunola, TB. Pastoralism as a New Phase of Terrorism in Nigeria. Global Journal of Human Social Sciences. 2017; 17(4): 20-24.

30. Michael OB. Achieving Sustainable Economic Development in Nigeria through Financial Inclusion in the Agric Sector. Journal of Global Economics. 2016; 4(2): 1-5.

31. Nze, E., (2015). The Effects of Migration by Nomadic Farmers in the Livelihoods of Rural Crop Farmers in Enugu State, Nigeria. Global Journal of Science Frontier Research: D Agriculture and Veterinary, 15 3(10), 20-28.

32. Odoh SI. Chilaka FC. Climate Change and Conflict in Nigeria: A Theoretical and Empirical Examination of the Worsening Incidence of Conflicts between Fulani Herdsmen and Farmers in Northern Nigeria. Arabian Journal of Business and Management Review (Oman Chapter). 2012; 2(1):110-124.

33. Ogbo AI, Eneh Nnajiofor C J, Agbaeze EK, Chukwu BI. Isijola DO. Strategies for achieving sustainable economy in Nigeria taking into consideration the acceptable stakeholders. African Journal of Business Management. 2017; 11(19): 582-589. DOI:10.5897/AJBM2017.8191
34. Ogo-Oluwa SO. Anti-Grazing Policy and Conflict Resolution between Fulani Herdsmen and Farmers in Ekiti State. Asian Research Journal of Arts \& Social Sciences. 2017; 4(1): 1-13. DOI : 10.9734/ ARJASS/2017/35979

35. Okeke E O. Conflicts between Fulani Herdsmen and Farmers in Central and Southern Nigeria: Discussion the Proposed Establishment of Grazing Routes and Reserves. International Journal of Arts and Humanities. 2014;3(1): 66-84.

36. Okoli, A.C. and Atelhe, G.A. (2014), Nomads against Natives: A Political Ecology of Herders/Farmers Conflicts in Nassarawa State, Nigeria, American International Journal of Contemporary Research, 4(2), 76-88.

37. Olajide OT, Akinlabi BH, Tijani AA. Agriculture Resources and Economic Growth in Nigeria. European Scientific Journal (October Edition). 2012; 8(22): 103-115.

38. Olaniyon AF, Okeke-Uzodike U. The Cattle are Ghanaians but the Herders are Strangers: Farmer-Herder Conflicts, Expulsion Policy and Pastoralist Question in Agogo, Ghana. African Studies Quarterly. 2015;15(2): 53-67.

39. Olayoku A P. Trends and Patterns of Cattle Grazing and Rural Violence in Nigeria (2006- 2014).Nigeria Watch Project. 2014; Infra-Nigeria Working Papers Series. No 34.

40.0li N P, Ibekwe CC, Nwankwo IU. Prevalence of Herdsmen and Farmers Conflict in Nigeria, International Journal of Innovative Studies in Sociology and Humanities. 2018; 3(1): 30-39.

41. Olugbenga E O. Peace by Pieces: The Politics of Herdsmen Attacks, Grazing Regulation Law, 2016. Advances in Social Sciences Research Journal. 2017; 4(5): 72-89. DOI:10.14738/assrj.45.2810

42. Orheruata AM. Omoyakhi JM. Livestock Environmental Interaction: Issues and Options in Nigeria. Journal of Applied Science and Environmental Management. 2007; 12(2): 129-133.

43. Rojas-Downing MM, Nejadhashemi AP, Harrigan T, woznicki SA. Climate Change and Livestock: Impacts, Adaptation, and Mitigation. Climate Risk Management. 2017; 16: 145-163. DOI: $10.1016 /$ j.crm.2017.02.001 